\title{
KAJIAN IN VITRO SUBTITUSI KONSENTRAT DENGAN PENGGUNAAN LIMBAH PERKEBUNAN SINGKONG YANG DISUPLEMENTASI KOBALT (Co) DAN SENG (Zn) DALAM RANSUM DOMBA
}

\section{IN VITRO STUDY ON SUBSTITUTION OF CONCENTRATE BY CASSAVA PLANTATION WASTE SUPPLEMENTED WITH COBALT (Co) AND ZINC (Zn) IN SHEEP RATION}

\author{
Iman Hernaman*, Atun Budiman, Siti Nurachma, dan Kundrat Hidajat \\ Fakultas Peternakan, Universitas Padjadjaran, Sumedang, 45363
}

Submitted: 23 February 2015, Accepted: 7 May 2015

\begin{abstract}
INTISARI
Penelitian ini bertujuan untuk mengetahui pengaruh subtitusi konsentrat dengan limbah perkebunan singkong yang disuplementasi kobalt dan seng dalam ransum domba. Kajian in vitro digunakan dalam penelitian ini. Data yang terkumpul dianalisis menggunakan uji Duncan dari Rancangan Acak Lengkap dengan empat perlakuan dan empat ulangan. Ransum perlakuan terdiri atas R1 $=50 \%$ rumput lapangan + $50 \%$ konsentrat, $\mathrm{R} 2=50 \%$ rumput lapangan $+50 \%$ konsentrat $+5 \mathrm{ppm}$ kobalt $+30 \mathrm{ppm}$ seng, $\mathrm{R} 3=50 \%$ rumput lapangan $+50 \%$ limbah perkebunan singkong, $\mathrm{R} 4=50 \%$ rumput lapangan $+50 \%$ limbah perkebunan singkong $+5 \mathrm{ppm}$ kobalt $+30 \mathrm{ppm}$ seng. Hasil menunjukkan bahwa konsentrasi asam lemak volatil dan $\mathrm{NH}_{3}$, serta kecernaan bahan kering dan organik pada ransum yang mengandung konsentrat lebih tinggi $(\mathrm{P}<0,05)$ dibandingkan limbah perkebunan singkong. Konsentrasi asam lemak volatil dan $\mathrm{N}$ $\mathrm{NH}_{3}$ pada ransum yang mengandung limbah perkebunan singkong masih dalam kisaran normal dengan kecernaan bahan kering dan organik di atas 50\%. Suplementasi kobalt dan seng dapat meningkatkan $(\mathrm{P}<0,05)$ asam lemak volatil serta kecernaan bahan kering dan organik pada perlakuan ransum yang mengandung konsentrat, sebaliknya suplementasi kobalt dan seng tidak berpengaruh terhadap asam lemak volatil dan kecernaan bahan kering dan organik pada ransum yang mengandung limbah perkebunan singkong. Dari penelitian ini dapat disimpulkan bahwa limbah perkebunan singkong memiliki potensi sebagai pakan ruminansia, namun tidak dapat menggantikan konsentrat. Suplementasi kobalt dan seng tidak efektif dalam meningkatkan fermentabilitas dan kecernaan limbah perkebunan singkong.
\end{abstract}

(Kata kunci: Asam lemak volatil, Domba, In vitro, Kecernaan, N-NH $\mathrm{N}_{3}$ Limbah perkebunan singkong)

\section{ABSTRACT}

This research was aimed to investigate the effect of concentrate substitution with cassava plantation waste supplemented with cobalt and zinc in sheep ration. In vitro study was used in this experiment. Collected data were analyzed by Duncan's test from Completely Randomized Design with four treatments and four replications. The experiment rations were $R 1=50 \%$ native grass $+50 \%$ concentrate, $R 2=50 \%$ native grass $+50 \%$ concentrate $+5 \mathrm{ppm}$ cobalt $+30 \mathrm{ppm}$ zinc, $R 3=50 \%$ native grass $+50 \%$ cassava plantation waste, $R 4=50 \%$ native grass $+50 \%$ cassava plantation waste $+5 \mathrm{ppm}$ cobalt $+30 \mathrm{ppm}$ zinc The results showed that utilization of concentrate increased volatile fatty acid and $\mathrm{N}-\mathrm{NH}_{3}$ concentration, and digestibility of dry and organic matter compared with cassava plantation waste. Volatile fatty acid and $\mathrm{N}$ $\mathrm{NH}_{3}$ in sheep ration containing cassava plantation waste were still in normal range with dry and organic matter digestibility were up to $50 \%$, but supplementation of cobalt and zinc had the same effect $(P>0.05)$. It is concluded that cassava plantation waste can be used as sheep feed, but did not substitute concentrate. Supplementation of cobalt and zinc was not effective to improve fermentability and digestibility of cassava plantation waste.

(Key words: Cassava plantation waste, Digestibility, In vitro, $\mathrm{N}-\mathrm{NH}_{3}$, Sheep, Volatile fatty acid)

\footnotetext{
* Korespondensi (corresponding author):

Telp. +62 8122449998

E-mail: iman_hernaman@yahoo.com
} 


\section{Pendahuluan}

Budidaya singkong menghasilkan limbah berupa daun, batang dan kulit yang akan mencemari lingkungan di lokasi produksi, padahal limbah tersebut masih mengandung biomasa yang dapat dimanfaatkan sebagai pakan ruminansia. Penggunaan limbah perkebunan dan pertanian sampai saat ini hanya sebesar $30-40 \%$ dari potensi yang ada (Indraningsih et al., 2012).

Daun, batang, dan kulit singkong memiliki keunggulan masing-masing. Daun singkong mengandung protein tinggi, sedangkan batang sebagai sumber serat dan kulit sebagai sumber pati dalam bentuk bahan ekstrak tanpa nitrogen (BETN). Proporsi dari ketiga limbah tersebut dalam bahan kering, masing-masing sebesar 29, 29, dan $42 \%$ (Hernaman et al., 2010). Hasil analisis proksimat dari campuran ketiga limbah singkong tercatat adalah protein kasar $14,50 \%$, lemak kasar $5,17 \%$, serat kasar $18,24 \%$, BETN $56,68 \%$, abu $5,41 \%$, dan total digestible nutrients (TDN) 71,33\% (Hernaman et al., 2010). Kandungan protein kasar dan TDN-nya setara dengan kandungan pada konsentrat ruminansia yang dijual di pasaran, yaitu berkisar $12-14 \%$ dan $65-70 \%$. Meskipun demikian, limbah singkong memiliki racun berupa HCN (Jianping dan Yinong, 2005). Gangguan kandungan $\mathrm{HCN}$ dapat terkurangi dengan adanya bantuan proses fermentasi oleh mikrobia rumen (Prasojo et al, 2013).

Di sisi lain, intensifikasi penggunaan lahan untuk perkebunan singkong berakibat pada defisiensi mineral tertentu seperti seng dan kobalt. Kedua mineral tersebut berperan dalam mencerna pakan di dalam rumen (Krisidayova et al., 2001), sehingga suplemetasi seng dan kobalt dalam ransum berbasis limbah perkebunan singkong menjadi penting dalam meningkatkan fermentabilitas dan kecernaan dalam rumen. Penelitian ini bertujuan untuk mengetahui pengaruh subtitusi konsentrat dengan limbah perkebunan singkong yang disuplementasi kobalt dan seng dalam ransum domba.

\section{Materi dan Metode}

\section{Ransum percobaan}

Limbah perkebunan singkong seperti daun, batang dan kulit singkong dicampur dengan proporsi 29,29 , dan $42 \%$ berdasarkan bahan kering, kemudian dikeringkan dan digiling untuk disiapkan dalam pelaksanaan in vitro. Rumput lapangan diperoleh dari sekitar kampus, sedangkan konsentrat dibuat dari hasil mencampur berbagai bahan pakan yang dijual di pasaran. Konsentrat ini diproduksi oleh Divisi Pakan KUD Tandangsari, Kecamatan Tanjungsari, Kabupaten Sumedang sebagai konsentrat komersial (Tabel 1). Kobalt dan seng dibeli dari toko kimia sebagai senyawa seng-asetat dan kobalt-sulfat. Masing-masing bahan tersebut dibuat ransum perlakuan sebanyak 4 ulangan seperti yang disajikan pada Tabel 2 .

\section{Pelaksanaan in vitro}

Pelaksanaan in vitro dilakukan 2 tahap dengan metode Tilley dan Terry (1963). Sampel ditimbang sebesar $\pm 0,5 \mathrm{~g}$, lalu dimasukan ke dalam tabung fermentor dan dicampur dengan larutan McDougall sebanyak $40 \mathrm{ml}$ sebagai larutan penyangga pengganti saliva dan cairan rumen domba sebanyak 10 $\mathrm{ml}$ yang diperoleh dari rumah potong hewan yang sebelumnya domba tersebut diberi pakan berbasis rumput lapangan. Kemudian dimasukkan ke dalam Waterbath pada suhu $\pm 39^{\circ} \mathrm{C}$. Tiga jam setelah inkubasi, sampel

Tabel 1. Kandungan bahan pakan

(nutrients content of feed ingredients)

\begin{tabular}{lccc}
\hline \hline $\begin{array}{c}\text { Kandungan nutrien bahan pakan } \\
\text { (nutrient contents) }\end{array}$ & $\begin{array}{c}\text { Rumput lapangan } \\
\text { (native grass) }\end{array}$ & $\begin{array}{c}\text { Konsentrat } \\
\text { (concentrate) }\end{array}$ & $\begin{array}{c}\text { Limbah perkebunan singkong } \\
\text { (cassava plantation waste) }\end{array}$ \\
\hline Bahan kering (\%) (dry matter (\%)) & 20,43 & 89,08 & 87,79 \\
Protein kasar (\%) (crude protein (\%)) & 8,42 & 14,65 & 14,50 \\
Lemak kasar (\%) (extract ether (\%)) & 4,11 & 8,94 & 5,17 \\
Serat kasar (\%) (crude fiber (\%)) & 24,87 & 14,44 & 18,24 \\
Bahan ekstrak tanpa nitrogen (\%) & 47,60 & 51,20 & 56,68 \\
(nitrogen free extract (\%)) & & & \\
Abu (\%) (ash (\%)) & 15,00 & 10,77 & 5,41 \\
Total digestible nutrients/TDN 1 (\%) & $62,75^{2)}$ & $77,52^{3)}$ & $71,33^{3)}$ \\
\hline
\end{tabular}

1) TDN dihitung berdasarkan rumus Sutardi (2001) (according to Sutardi (2001)):

2) TDN $\%=70,6+0,259 \%$ PK $+1,01 \%$ LK- $0,76 \%$ SK $+0,0991 \%$ BETN $(70,6+0,259 \% C P+1,01 \% E E-0,76 \% C F+0,0991 \% N F E)$

3) TDN $\%=2,79+1,17 \%$ PK+1,74\%LK- $0,295 \%$ SK $+0,810 \%$ BETN $(2,79+1,17 \% C P+1,74 \% E E-0,295 \% C F+0,810 \% N F E)$. 


\section{Prosedur pengukuran kecernaan}

Pada tahap I, tabung fermentor yang berisi sampel diinkubasikan selama 48 jam. Setelah itu ditambahkan $\mathrm{Hg}_{2} \mathrm{Cl}_{2} \quad 0,25$ ml untuk mematikan mikrobia selama 20 menit. Kemudian disentrifuse dengan kecepatan $10.000 \mathrm{rpm}$ selama 10 menit. Supernatan dipisahkan dan ke dalam endapan di dalam fermentor ditambahkan $5 \mathrm{ml}$ larutan pepsin $0,2 \%$ dalam suasana asam dengan aktivitas pepsin 1:10.000. Tahap II, tabung fermentor diinkubasikan kembali ke dalam waterbath selama 48 jam. Selama inkubasi tabung fermentor dikocok setiap 3 jam. Setelah fermentasi selesai, endapan disaring dengan kertas saring Whatman No. 41, kemudian dianalisis kadar bahan kering dan organiknya. Sebagai blanko digunakan cairan rumen domba tanpa perlakuan. Kecernaaan bahan kering $(\mathrm{KcBK})$ dan bahan organik (KcBO) dihitung dengan menggunakan persamaan sebagai berikut :

$$
\begin{aligned}
\operatorname{KcBK}(\%)= & \{[\mathrm{BK} \text { awal- }(\mathrm{BK} \text { residu-BK } \\
& \text { blanko)]/BK awal }\} \times 100 \% \\
\mathrm{KcBO}(\%)= & \{[\mathrm{BO} \text { awal- }(\mathrm{BO} \text { residu-BO } \\
& \text { blanko)]/BO awal }\} \times 100 \%
\end{aligned}
$$

Keterangan:

$\mathrm{BK}$ : bahan kering, BO: bahan organik.

Percobaan dirancang menggunakan Rancangan Acak Lengkap (RAL). Data yang terkumpul diuji dengan analisis ragam yang dilanjutkan dengan uji Duncan (Steel dan Torrie, 1993).

\section{Hasil dan Pembahasan}

Penggunaan limbah perkebunan singkong sebagai bagian ransum yang disumplementasi kobalt dan seng terhadap fermentabilitas dan kecernaan in vitro disajikan pada Tabel 3.

Konsentrasi asam lemak volatil dan N$\mathrm{NH}_{3}$ untuk masing-masing perlakuan menunjukkan nilai pada kisaran rerata 101,56-153,52 mM dan 10,91-15,61 mM. Nilai tersebut masih dalam kisaran normal karena menurut Sutardi (1978), kisaran normal asam lemak volatil dan $\mathrm{N}-\mathrm{NH}_{3}$ untuk menunjang pertumbuhan mikrobia dalam memfermentasi ransum dalam rumen adalah $80-160 \mathrm{mM}$ dan 4-12 mM. Kondisi ini berarti penggunaan limbah perkebunan singkong dapat memberikan pasokan nutrien yang optimal dalam proses fermentasi oleh mikrobia di dalam rumen, meskipun tampak bahwa konsentrasinya lebih rendah $(P<0,05)$ dibandingkan dengan perlakuan ransum yang mengandung konsentrat.

Asam lemak volatil yang rendah pada perlakuan ransum yang mengandung limbah perkebunan singkong diduga terkait dengan tingginya serat kasar dan rendahnya bahan ekstrak tanpa nitrogen (BETN) dibandingkan dengan penggunaan konsentrat (Tabel 2). Pati, gula dan bagian yang bukan serat yang tidak larut oleh eter dan bahan organik merupakan komponen utama dari BETN. Di rumen BETN akan mudah dicerna menjadi asam lemak volatil terutama akan menjadi asam propionate. Oleh karena itu, konsentrat yang kaya BETN akan menghasilkan produk asam lemak volatil yang lebih tinggi dibandingkan dengan limbah perkebunan singkong yang kaya serat (Tabel 1). Daya cerna BETN lebih tinggi dibandingkan dengan serat kasar (Astuti et al., 2009). Usman (2013) melaporkan bahwa perbedaan kondisi fermentasi di dalam rumen sangat dipengaruhi oleh perbedaan sumber karbohidrat pakan terutama kandungan serat kasarnya.

Suplai asam lemak volatil yang lebih tinggi $(P<0,05)$ pada perlakuan ransum yang mengandung konsentrat (Tabel 3) akan memberikan kesempatan bagi bakteri rumen khususnya bakteri proteolitik untuk tumbuh lebih banyak. Asam lemak volatil adalah produk fermentasi dalam rumen yang dibutuhkan sebagai sumber energi dan kerangka karbon dalam pembentukan sel mikrobia (Bergen, 1977) termasuk bakteri proteolitik. Populasi bakteri proteolitik diduga menjadi lebih banyak akibat tersedianya asam lemak volatil yang lebih tinggi, akibatnya akan meningkatkan kemampuan dalam mendegradasi komponen protein menjadi $\mathrm{N}-\mathrm{NH}_{3}$ yang lebih optimal. Dengan demikian, konsentrasi $\mathrm{N}-\mathrm{NH}_{3}$ pada perlakuan konsentrat lebih tinggi daripada ransum yang mengandung limbah perkebunan singkong. Russell dan Stobel (1993) menyatakan bahwa sumber karbohidrat dalam pakan yang mudah dicerna, menyebabkan pertumbuhan mikrobia menjadi lebih efisien dalam hal produksi ATP dan sintesis protein mikrobia.

Sementara itu, nilai $\mathrm{pH}$ untuk semua perlakuan menghasilkan nilai yang tidak berbeda nyata $(P>0,05)$ dengan kisaran $\mathrm{pH}$ adalah 6,95-6,96, meskipun konsentrasi asam lemak volatil dan $\mathrm{N}-\mathrm{NH}_{3}$ (Tabel 3) menunjukkan perbedaan yang nyata. Padahal 
Tabel 3. Rerata asam lemak volatil, $\mathrm{N}-\mathrm{NH}_{3}, \mathrm{pH}$, kecernaan bahan kering dan kecernaan bahan organik in vitro sebagai respon dari berbagai ransum perlakuan

(means of volatile fatty acids, $\mathrm{N}-\mathrm{NH}_{3}, \mathrm{pH}$, dry matter digestibility and organic matter digestibility as response to various ration treatments)

\begin{tabular}{|c|c|c|c|c|}
\hline Peubah & R1 & R2 & R3 & R4 \\
\hline $\begin{array}{l}\text { Asam lemak volatil (mM) (volatile fatty } \\
\text { acids }(m M) \text { ) }\end{array}$ & $132,44 \pm 7,10^{b}$ & $13,11 \pm 10,03^{a}$ & $01,56 \pm 7,21^{\mathrm{c}}$ & $06,25 \pm 10,98^{c}$ \\
\hline & 15,0 & 15,6 & $10,43=$ & $10,91 \pm 0$ \\
\hline $\mathrm{pH}$ & & & & \\
\hline $\begin{array}{l}\text { Kecernaan bahan kering (\%) (dry matter } \\
\text { digestibility (\%)) }\end{array}$ & 55,8 & $7 a$ & ab & $53,47 \pm 2,58^{b}$ \\
\hline $\begin{array}{l}\text { Kecernaan bahan organik (\%) (organic } \\
\text { matter digestibility (\%)) }\end{array}$ & $56,47 \pm 4,37^{\mathrm{ab}}$ & $59,75 \pm 1,33^{a}$ & $56,08 \pm 2,29^{a b}$ & $53,20 \pm 2,64^{b}$ \\
\hline \multicolumn{5}{|c|}{$\begin{array}{l}\text { R1: } 50 \% \text { rumput lapangan }+50 \% \text { konsentrat }(50 \% \text { native grass }+50 \% \text { concentrate }), R 2: 50 \% \text { rumput lapangan }+50 \% \\
\text { konsentrat }+5 \mathrm{ppm} \text { kobalt }+30 \mathrm{ppm} \text { seng }(50 \% \text { native grass }+50 \% \text { concentrate }+5 \mathrm{ppm} \text { cobalt }+30 \mathrm{ppm} \text { zinc }) \text {, } \\
R 3: 50 \% \text { rumput lapangan }+50 \% \text { limbah perkebunan singkong }(50 \% \text { native grass }+50 \% \text { cassava plantation waste }) \text {, } \\
R 4: 50 \% \text { rumput lapangan }+50 \% \text { limbah perkebunan singkong }+5 \mathrm{ppm} \text { kobalt }+30 \mathrm{ppm} \text { seng }(50 \% \text { native grass }+ \\
50 \% \text { cassava plantation waste }+5 \mathrm{ppm} \text { cobalt }+30 \mathrm{ppm} \text { zinc }) \text {. } \\
\text { a,b,c Superskrip yang berbeda pada baris yang sama menunjukkan perbedaan yang nyata }(P<0,05)(\text { different superscripts } \\
\text { at the same row showed significant differences }(P<0.05)) \text {. }\end{array}$} \\
\hline
\end{tabular}

menurut Sugoro et al. (2005) dan Hernaman et al. (2005) konsentrasi asam lemak volatil dan $\mathrm{N}-\mathrm{NH}_{3}$ mempengaruhi nilai $\mathrm{pH}$ cairan rumen. Kemungkinan hal tersebut disebabkan oleh adanya penggunaan larutan McDougall dalam pengujian in vitro. Larutan ini dimaksudkan sebagai larutan penyangga untuk menggantikan saliva yang berfungsi untuk mempertahankan $\mathrm{pH}$ dalam kondisi normal, yaitu 6,3-7. Bila kondisi tersebut tidak tercapai akan berdampak kepada kehidupan mikrobia rumen itu sendiri.

Sejalan dengan tingginya fermentabilitas pada ransum yang mengandung konsentrat yang ditunjukkan dengan kandungan asam lemak volatil dan $\mathrm{N}-\mathrm{NH}_{3}$ yang lebih tinggi (Tabel 3), maka kecernaan bahan kering dan organik juga menunjukkan nilai yang lebih tinggi $(P<0,05)$ dibandingkan dengan perlakuan yang mengandung limbah perkebunan singkong. Asam lemak volatil dan $\mathrm{N}-\mathrm{NH}_{3}$ adalah produk fermentasi dari karbohidrat dan protein pakan yang dibutuhkan bagi pertumbuhan bakteri rumen. Pertumbuhan mikrobia yang optimal dapat meningkatkan kecernaan bahan kering maupun bahan organik yang lebih baik (Hau et al., 2005). Serat kasar yang tinggi pada limbah perkebunan singkong (Tabel 1) juga mengurangi fermentabilitas yang menyebabkan berkurangnya kecernaan. Despal (2000) melaporkan bahwa semakin tinggi serat yang terkandung dalam pakan maka semakin rendah daya cernanya. Serat kasar yang tinggi diduga diikuti dengan kandungan lignin yang tinggi pula terutama pada bagian batang singkong, dimana senyawa lignin merupakan pembatas kecernaan pakan (Chaves et al. 2002).

Di sisi lain, $\mathrm{HCN}$ sebagai senyawa yang banyak ditemukan dalam bagian pada tanaman singkong (Jianping dan Yinong, 2005), tampaknya tidak berpengaruh besar terhadap kecernaan dengan selisih yang tidak terlalu besar dengan perlakuan penggunaan konsentrat yaitu berkisar $4 \%$ dan masih di atas $50 \%$. Hal ini disebabkan limbah singkong yang digunakan sudah dalam keadaan kering jemur, di mana proses pengeringan terbukti mampu mengurangi kadar $\mathrm{HCN}$ (Tweyongyere dan Katongole, 2002) yang tidak berdampak pada fermentabilitas dan kecernaan pakan di rumen.

Suplementasi kobalt dan seng tampak berpengaruh nyata $(P<0,05)$ pada ransum yang mengandung konsentrat, sedangkan pada ransum yang mengandung limbah perkebunan singkong, pengaruhnya tidak tampak bahkan lebih rendah dibanding dengan perlakuan yang lainnya terhadap fermentabilitas dan kecernaan. Mineral yang ditambahkan dalam ransum perlakuan adalah dalam bentuk mineral anorganik, di mana di dalam rumen akan membentuk senyawa kompleks tak larut dengan anion lain (Church, 1984). Serat yang tinggi pada limbah perkebunan singkong diduga memiliki kemampuan mengikat kobalt dan seng menjadi senyawa yang lebih kompleks, sehingga mineral tersebut tidak banyak dimanfaatkan oleh mikrobia rumen. Tortuero et al. (1994) melaporkan bahwa ransum kelinci yang banyak mengandung serat kasar terutama komponen selulosa menyebabkan 
absorpsi $\mathrm{Fe}, \mathrm{Mn}, \mathrm{Mg}$ dan $\mathrm{Zn}$ menjadi rendah dan banyak dieksresikan melalui urine dan feses. Suplementasi kobalt mampu memperbaiki fermentabilitas serat (Krisidayova et al., 2001), sedangkan seng merupakan koenzim yang dihasilkan oleh mikrobia rumen yang berperan dalam kecernaan pakan.

\section{Kesimpulan}

Limbah perkebunan singkong berpotensi sebagai pakan ruminansia, tetapi tidak dapat menggantikan konsentrat. Suplementasi kobalt dan seng tidak efektif dalam meningkatkan fermentabilitas dan kecernaan limbah perkebunan singkong.

\section{Ucapan Terima Kasih}

Terimakasih disampaikan kepada Direktorat Jenderal Pendidikan Tinggi, Departemen Pendidikan Nasional atas bantuan dana penelitian melalui dana HIBAH BERSAING Tahun 2010.

\section{Daftar Pustaka}

AOAC. 2005. Official Methods of Analysis. $18^{\text {th }}$ edn. Association of Official Agricultural Chemists. Washington, DC.

Astuti, A., A. Agus, dan S. P. S. Budhi. 2009. Pengaruh penggunaan high quality feed supplement terhadap konsumsi dan kecernaan nutrien sapi perah awal laktasi. Buletin Peternakan 33: 81-87.

Bergen, W. G. 1977. Factors affecting growth yields of micro-organisms in the rumen. Trop. Anim. Prod. 4: 13-20.

Chaves, A. V., G. C. Waghorn, I. M. Brookes and D. Hedderley. 2002. Digestion kinetics of ryegrass. Proceedings of the New Zealand Society of Animal Production 62: 157-162.

Church, D. C. 1984. Livestock Feeds and Feeding. $2^{\text {nd }}$ edn. O\&B Books Inc. Corvallis, Oregon.

Despal. 2000. Kemampuan komposisi kimia dan kecernaan in vitro dalam mengestimasi kecernaan in vivo. Media Peternakan 23: 84-88.

Hau, D. K, M. Nenobais, J. Nulik, dan N. G. F. Katipana. 2005. Pengaruh probiotik terhadap kemampuan cerna mikroba rumen sapi Bali. Seminar Nasional Teknologi Peternakan dan Veteriner.
Hernaman, I. U. H. Tanuwiria, dan M. F. Wiyatna. 2005. Pengaruh Penggunaan Berbagai Tingkat Kulit Kopi dalam Ransum Penggemukan Sapi Potong terhadap Fermentabilitas Rumen dan Kecernaan In-Vitro. Bionatura 7: 46-50.

Hernaman, I. A. Budiman, S. Nurachma, dan K. Hidajat. 2010. Potensi Limbah Tanaman Singkong sebagai Pakan Ruminansia. Prosiding Seminar Nasional Peternakan Berkelanjutan ke2: Sistem Produksi Berbasis Ekosistem Lokal, Fakultas Peternakan Universitas Padjadjaran Jatinangor 4 November 2010.

Indraningsih, R. Widiastuti, dan Y. Sani. 2012. Limbah Pertanian dan Perkebunan sebagai Pakan Ternak : Kendala dan Prospeknya. Lokakarya Nasional IPTEK dalam Pengendalian Penyakit, Strategi pada Ternak Ruminansia. Bogor.

Jianping, L. and T. Yinong. 2005. Use of cassava root meal and leaf silage for animal feeding in Yunnan Province of China. The use of cassava roots and leaves for on farm animal feeding. Editor R.H Howler. Proceeding of A Regional Workshop. Hue City. Vietnam.

Krisidayova, S., P. Sviatko, P. Siroka and D. Jalc. 2001. Effect of elevated cobalt intake on fermentative parameters and protozoan population in RUSITEC. Anim. Feed. Sci. Tech. 91: 223-232.

Prasojo, A. P. W., F. M. Suhartati, dan S. Rahayu. 2013. Pemanfaatan kulit singkong fermentasi menggunakan leuconostoc mesenteroides dalam pakan pengaruhnya terhadap n-nh3 dan VFA (in vitro). Jurnal IImiah Peternakan 1: 397-404.

Russell, J. B. and H. J. Stobel. 1993. Microbial energetics. In: Quantitative Aspects of Ruminant Digestion and Metabolism. J. M. Forbes. and J. France (eds). CAB International. Wallingford, UK.

Steel, R. G. D. and J. H. Torrie. 1993. Prinsip dan Prosedur Statistika. PT. Gramedia Pustaka Utama.

Sugoro, I. I. Gobel, dan N. Lelananingtyas. 2005. Pengaruh probiotik khamir terhadap fermentasi dalam cairan rumen secara in vitro. Seminar Nasional Teknologi Peternakan dan Veteriner. Bogor 12-15 September 2005. 
Sutardi, T. 1978. Ikhtisar Ruminologi. Bahan Kursus Peternakan Sapi Perah. Kayu Ambon. Dirjen Peternakan-FAO.

Sutardi, T. 2001. Revitalisasi peternakan sapi perah melalui penggunaan ransum berbasis limbah perkebunan dan suplementasi mineral organik. Laporan akhir RUT VIII 1. Kantor Kementrian Negara Riset dan Teknologi dan LIPI.

Tilley, J. M. A. and R. A Terry. 1963. A two stage technique for the in vitro digestion of forage crops. J. British. Grassl. Soc. 18: 104-111.

Tortuero, F., J. Rioperez, C. Cosin, J. Barrera and M. L. Rodriguez. 1994. Effects of dietary fiber sources on volatile fatty acid production, intestinal microflora and mineral balance in rabbits. Anim. Feed Sci. Technol. 48: 1-14.
Tweyongyere, R. and Katongole. 2002. Cyanogenic potential of cassava peels and their detoxification for utilization as livestock feed. Vet. Hum. Toxicol. 44: 366-369.

Usman, Y. 2013. Pemberian pakan serat sisa tanaman pertanian (jerami kacang tanah, jerami jagung, pucuk tebu) terhadap evolusi $\mathrm{pH}, \mathrm{N}-\mathrm{NH}_{3}$ dan VFA di dalam rumen sapi. Agripet. 13: 53-58. 